\title{
Modelling the impact of retention-detention units on sewer surcharge and peak and annual runoff reduction
}

Locatelli, Luca; Gabriel, S.; Mark, O.; Mikkelsen, Peter Steen; Arnbjerg-Nielsen, Karsten; Taylor, Heidi; Bockhorn, Britta; Larsen, H.; Kjølby, M. J.; Steensen Blicher, Anne

Total number of authors:

11

Published in:

Water Science and Technology

Link to article, DOI:

10.2166/wst.2015.044

Publication date:

2015

Document Version

Peer reviewed version

Link back to DTU Orbit

Citation (APA):

Locatelli, L., Gabriel, S., Mark, O., Mikkelsen, P. S., Arnbjerg-Nielsen, K., Taylor, H., Bockhorn, B., Larsen, H., Kjølby, M. J., Steensen Blicher, A., \& Binning, P. J.' (2015). Modelling the impact of retention-detention units on sewer surcharge and peak and annual runoff reduction. Water Science and Technology, 71(6), 898-903. https://doi.org/10.2166/wst.2015.044

\section{General rights}

Copyright and moral rights for the publications made accessible in the public portal are retained by the authors and/or other copyright owners and it is a condition of accessing publications that users recognise and abide by the legal requirements associated with these rights.

- Users may download and print one copy of any publication from the public portal for the purpose of private study or research.

- You may not further distribute the material or use it for any profit-making activity or commercial gain

- You may freely distribute the URL identifying the publication in the public portal 


\title{
Modelling the impact of retention-detention units on sewer surcharge and peak and annual runoff reduction
}

\author{
Luca LOCATELLI $^{1}$, Søren GABRIEL ${ }^{2}$, Ole MARK ${ }^{3}$, Peter Steen MIKKELSEN ${ }^{1}$, Karsten \\ ARNBJERG-NIELSEN ${ }^{1}$, Heidi TAYLOR ${ }^{2}$, Britta BOCKHORN ${ }^{4}$, Hauge LARSEN ${ }^{2}$, Morten \\ Just KJØLBY ${ }^{3}$, Anne Steensen BLICHER ${ }^{2}$, Philip John BINNING ${ }^{1}$ \\ ${ }^{1}$ Technical University of Denmark, Denmark \\ ${ }^{2}$ Orbicon, Denmark \\ ${ }^{3}$ DHI, Denmark \\ ${ }^{4}$ University of Copenhagen, Denmark
}

\begin{abstract}
Stormwater management using Water Sensitive Urban Design (WSUD) is expected to be part of future drainage systems. This paper aims to model the combination of local retention units, such as soakaways, with subsurface detention units. Soakaways are employed to reduce (by storage and infiltration) peak and volume stormwater-runoff, however large retention volumes are required for a significant peak reduction. Peak runoff can therefore be handled by combining detention units with soakaways. This paper models the impact of retrofitting retention-detention units for an existing urbanized catchment in Denmark.

The impact of retrofitting a retention-detention unit of $3.3 \mathrm{~m}^{3} / 100 \mathrm{~m}^{2}$ (volume/imperviousarea) was simulated for a small catchment in Copenhagen using MIKE URBAN. The retention-detention unit was shown to prevent flooding from the sewer for a 10-years rainfall event. Statistical analysis of continuous simulations covering 22 years showed that annual stormwater-runoff was reduced by $68-87 \%$, and that the retention volume was on average $53 \%$ full at the beginning of rain events. The effect of different retention-detention volume combinations was simulated and results showed that allocating $20-40 \%$ of a soakaway volume to detention would significantly increase peak runoff reduction with a small reduction in the annual runoff.
\end{abstract}

\section{Keywords}

Detention; modelling; soakaways; Water Sensitive Urban Design

\section{INTRODUCTION}

Water Sensitive Urban Design (WSUD) aims at improving stormwater management and can be part of climate change adaptation strategies (Wong and Brown, 2009). Soakaways coupled with detention units, referred to as retention-detention units, increase groundwater recharge and reduce annual stormwater-runoff, pipe surcharge and Combined Sewer Overflows (CSOs).

Existing hydrological models that include WSUD elements are presented by Elliott and Trowsdale, 2007.

Several studies have presented models for the hydrological performance of single soakaways (Roldin et al., 2013; Roldin et al., 2012; Freni et al., 2009; Warnaars et al., 1999). These models were validated against either observed data or physical based models and then used for short term predictions of runoff from single soakaways. 
Other studies have modeled the impact of implementing soakaways at catchment scale (Roldin et al., 2012; Maimone et al., 2011; Antia, 2008), examining the effect on CSOs and groundwater response. None of these studies have combined detention volumes to soakaways and statistically quantified the continuous hydrological performance of retention-detention units.

The aim of this study was to model the impact of retention-detention units on sewer surcharge and annual runoff reduction. Moreover, the water content of storage units at the beginning of rain events was estimated in order to determine the proper initial conditions when modelling single events. Further, we model how different retention-detention volume combinations affect annual and peak runoff reduction in order to assist in combined soakaway-detention system design.

\section{TOOLS AND METHODS}

\section{The retention-detention unit}

Figure 1 shows the retention-detention unit that consists of the following elements:

- Water inlet. A pipe that diverts stormwater runoff into the retention-detention unit.

- Retention volume (Soakaway). A volume aimed for storage and infiltration.

- Detention storage. A volume aimed to delay peak flows.

- Overflow pipes. Pipes diverting water from the storage to the sewer system in case of overflow.

- Valve. To control the maximum flow rate from the detention storage to the sewer system.

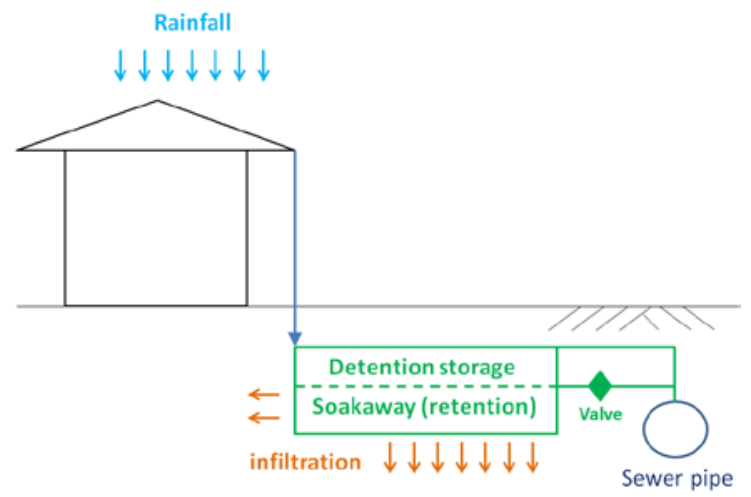

Figure 1. The retention-detention unit.

\section{The retention-detention unit design}

The retention-detention unit consists of a detention volume above a soakaway volume. The soakaway aims to reduce annual runoff and the detention storage aims to reduce peak overflow to the sewer. Soakaway and detention volumes are designed using Danish design tools (Petersen et al., 1995). The design aims at accommodating the stormwater volume accumulated during design events with a specified return period.

\section{The case study area}

The street of Sandbygårdvej is located in Copenhagen (Denmark) and is served by a combined sewer system (Figure 2). The reduced (impermeable) catchment area connected to the local sewer pipe is 0.67 hectares consisting of 55\% roofs, $20 \%$ front and backyards and $25 \%$ street and sidewalks. Sandbygårdvej lies on a topographic highpoint (32-34 m above mean sea level) and has an average slope of approximately $2 \%$. The near surface geology is dominated by low permeability clay tills. The saturated hydraulic conductivity was measured 
at $40 \mathrm{~cm}$ depth below terrain with a Guelph Permeameter at 20 random points on a $100 \times 100 \mathrm{~m}$ field located nearby with similar geological conditions. Results showed a saturated hydraulic conductivity with a geometric mean of $8.2 \cdot 10^{-7} \mathrm{~m} / \mathrm{s}$, a standard deviation of $1.8 \cdot 10^{-6} \mathrm{~m} / \mathrm{s}$, and no spatial correlation between the measuring points.

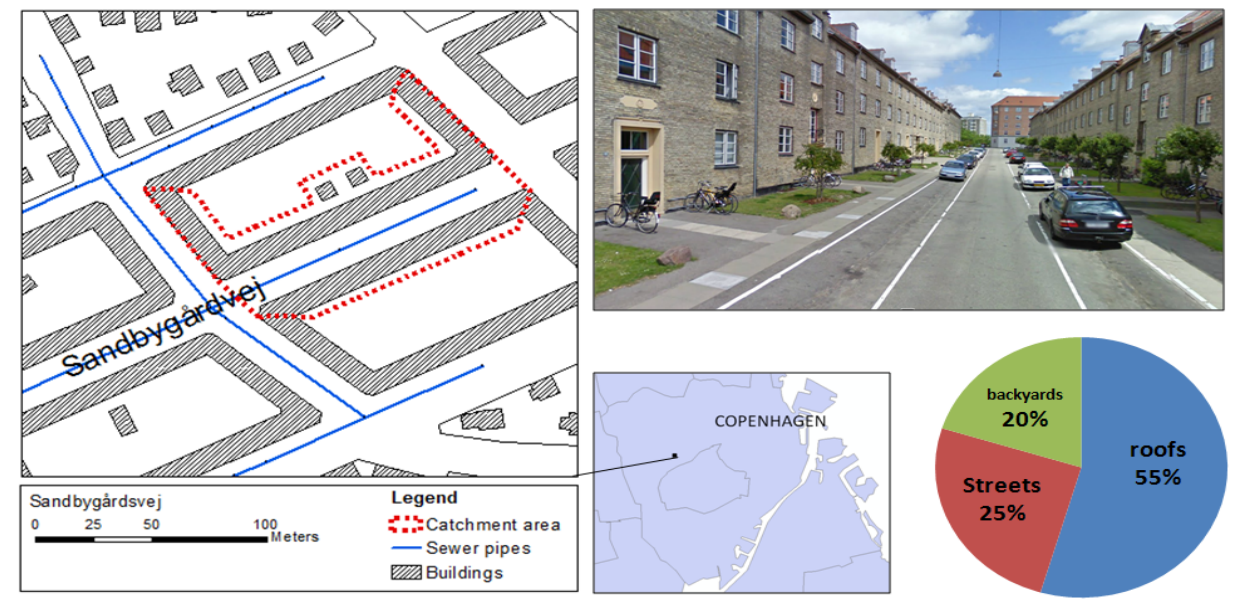

Figure 2. The case study area.

\section{The model}

The urban drainage model used in this study was a MIKE URBAN/MOUSE (Andersen et al., 2004) model set up by the companies HOFOR and Rambøll. The model covers a large area and it divides the area into several sub-catchments described by lumped parameters and connected to the sewer system at specified manholes. The surface runoff was calculated using the time-area method and the resulting hydrograph used as input to the hydrodynamic pipe flow model. Boundary conditions include dry weather flows in the local stream and water levels at lakes and at the estuary. The model includes pipe dimensions (slope, diameter, length, roughness) and connected surfaces (roofs, streets, backyards). Green areas were assumed to have a high infiltration capacity and therefore did not contribute to stormwater runoff.

The soakaway model integrated into MIKE URBAN (Roldin et al., 2012) was used to simulate the retention-detention units. The soakaway model is based on mass balance for the soakaway with infiltration rates $(f)$ described as:

$$
f=k l w+k 2 h(l+w)
$$

Where $k$ is the soil hydraulic conductivity, $l$ is length, $w$ the width and $h$ is the water level in the soakaway.

The retention-detention unit was modelled as a 'basin' in MIKE URBAN with infiltration rates determined from the soakaway model. The 'basin' was connected to the sewer system by 2 overflow pipes, one with a maximum rate (the lowest pipe) and the other without an outflow control.

\section{Sewer surcharge}

The impact of retention-detention units on sewer surcharge was modelled using single event simulation. A Baseline scenario and Retention-detention scenario was simulated. The input rainfall was a 4 hours duration Chicago Design Storm (CDS) (Keifer and Chu, 1957) event of 10 -years return period (5-minutes rainfall-intensity $\approx 90 \mathrm{~mm} / \mathrm{h}$ ) as determined using the Danish regional IDF curves (Madsen et al., 2009). The soakaway was designed for a 0.1-year 
119 return period (19 $\mathrm{mm}$ of storage capacity) and the detention volume for a 10 -year return 120 period (14 mm of storage capacity) (Table 1, Unit 1). The designed detention volume is a 121 function of the maximum flow rate through the 'valve' (see Figure 1) which was determined 122 as explained later in this section.

The Baseline scenario simulated the maximum water level in the drainage system. This was then used to quantify the impervious area to be disconnected from the sewer in order to avoid sewer surcharge. The area to be disconnected was determined by model trial and error and the resulting area was connected to the retention-detention units.

128 The Retention-detention scenario simulated the water level in the drainage system in the 129 presence of the designed retention-detention units with several units modeled as a single 130 aggregated unit according to the method presented by Roldin et al. (2012). The error 131 introduced by upscaling was assumed to be comparable with the error calculated by Roldin et 132 al. (2012) that was on average 5\%. Initial conditions for the retention-detention system were 133 chosen as shown in the section 'Annual water balance and initial conditions'. The Retention134 detention scenario was an iterative process where the maximum controlled outflow rate from 135 the detention volume to the sewer (the flow through the 'valve' in Figure 1) was adjusted in 136 order to avoid sewer surcharge during the simulation. The maximum outflow rate obtained 137 was used to design the detention volume.

\section{Annual water balance and initial conditions}

139 The annual water balance and initial conditions of single retention-detention units were 140 modeled using 22-years of continuous simulations with a 1-minute time step and input 141 rainfall time series from Copenhagen.

142 Five different design return periods (Table 1, Unit 2-6) were considered for the soakaway. 143 The detention volume was not included in these simulations as it was found to have a small 144 impact on the annual water balance and initial conditions. This is because detention time 145 scale is about an hour, whereas the infiltration process from soakaways occurs over a period 146 of days. Moreover, the detention volume is exploited only few times a year (i.e. 147 approximately 10 times a year if the soakaway is designed for a 0.1-year return period). 
Table 1. Retention-detention units

\begin{tabular}{|c|c|c|c|c|c|c|c|c|}
\hline \multirow[b]{2}{*}{$\begin{array}{l}\text { Section name } \\
\text { in the paper }\end{array}$} & \multirow[b]{2}{*}{ Unit } & \multicolumn{3}{|c|}{ Retention volume (soakaway) } & \multicolumn{3}{|c|}{ Detention volume } & \multirow{2}{*}{$\begin{array}{l}\text { Total } \\
\text { retention- } \\
\text { detention } \\
\text { volume }\end{array}$} \\
\hline & & $\begin{array}{l}\text { Design } \\
\text { return } \\
\text { period }^{*}\end{array}$ & $\begin{array}{l}\text { Retention } \\
\text { capacity }\end{array}$ & $\begin{array}{l}\text { Soakaway } \\
\text { volumel } \\
\text { impervious } \\
\text { area }\end{array}$ & $\begin{array}{l}\text { Design } \\
\text { return } \\
\text { period }\end{array}$ & $\begin{array}{l}\text { Detention } \\
\text { capacity }\end{array}$ & $\begin{array}{l}\text { Detention } \\
\text { volume/ } \\
\text { impervious } \\
\text { area } \\
\end{array}$ & \\
\hline & & [years] & {$[\mathrm{mm}]$} & $\begin{array}{l}{\left[\mathrm{m}^{3} /\right.} \\
\left.100 \mathrm{~m}^{2}\right]\end{array}$ & [years] & {$[\mathrm{mm}]$} & {$\left[\mathrm{m}^{3} / 100 \mathrm{~m}^{2}\right]$} & {$\left[\mathrm{m}^{3} / 100 \mathrm{~m}^{2}\right]$} \\
\hline $\begin{array}{l}\text { Sewer } \\
\text { surcharge }\end{array}$ & 1 & 0.1 & 19 & 1.9 & 10 & 14 & 1.4 & 3.3 \\
\hline \multirow{5}{*}{$\begin{array}{l}\text { Annual water } \\
\text { balance and } \\
\text { initial } \\
\text { conditions }\end{array}$} & 2 & 0.1 & 19 & 1.9 & & 0 & 0 & \\
\hline & 3 & 0.5 & 37 & 3.7 & & 0 & 0 & \\
\hline & 4 & 1 & 46 & 4.6 & & 0 & 0 & \\
\hline & 5 & 2 & 56 & 5.6 & & 0 & 0 & \\
\hline & 6 & 5 & 69 & 6.9 & & 0 & 0 & \\
\hline \multirow{6}{*}{$\begin{array}{l}\text { Retention- } \\
\text { detention } \\
\text { volume } \\
\text { combinations }\end{array}$} & 7 & & 0 & 0 & & 33 & 3.3 & 3.3 \\
\hline & 8 & & 6.6 & 0.7 & & 26.4 & 2.6 & 3.3 \\
\hline & 9 & & 13.2 & 1.3 & & 19.8 & 2.0 & 3.3 \\
\hline & 10 & & 19.8 & 2.0 & & 13.2 & 1.3 & 3.3 \\
\hline & 11 & & 26.4 & 2.6 & & 6.6 & 0.7 & 3.3 \\
\hline & 12 & & 33 & 3.3 & & 0 & 0 & 3.3 \\
\hline
\end{tabular}

\section{Retention-detention volume combinations}

151 The impact of different detention-retention volume combinations on peak runoff and annual water balance from single units was modeled with the same continuous simulations as shown above. Several volume combinations of retention-detention were modeled (see Table 1, Unit 7-12). Results show peak reduction, defined as average reduction for the modeled single events with a return period between 1 and 10 years; and annual runoff reduction, defined as the average annual runoff reduction for the 22 year period.

\section{RESULTS}

\section{Sewer surcharge}

159 The Baseline scenario showed that the maximum water level observed in the sewer system 160 during the single event simulation was above terrain (flooding). The area that must be disconnected in order to avoid flooding was found to be approximately $88 \%$. The discharging capacity of the local pipe was reduced due to backwater from the downstream pipe, having a high water level due to water coming from outside of the case study area; this explains the high percentage of disconnection required.

165 Figure 3 shows the maximum water level observed in the sewer system for the Retention166 detention scenario. The results show that sewer surcharge can be avoided by connecting 88\% 167 of the impervious area to the retention-detention unit. Similar results were obtained by Elliot 168 et al. (2009) and Peters et al. (2007), who showed that stormwater infiltration devices reduce 169 hydraulic peak loads. The maximum discharge capacity from the detention volume to the 170 sewer system was found to be $25 \mathrm{l} / \mathrm{s}$. The maximum discharge rate was used together with the 171 intensity distribution of a 10-year return period rainfall event to find the required detention 172 volume of $1.4 \mathrm{~m}^{3}$ for every $100 \mathrm{~m}^{2}$. 

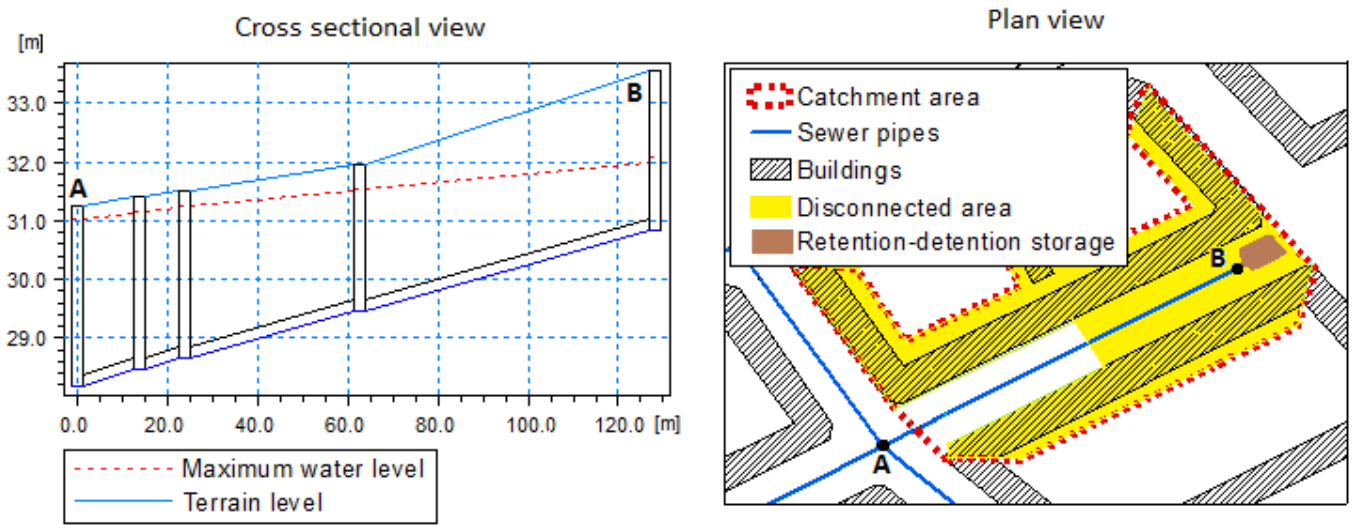

Figure 3. Maximum water level observed in the Retention-detention scenario.

\section{Annual water balance and initial conditions}

176

177

178

179

180

181

182

183

184

185

186

187

188

189

190

191

192

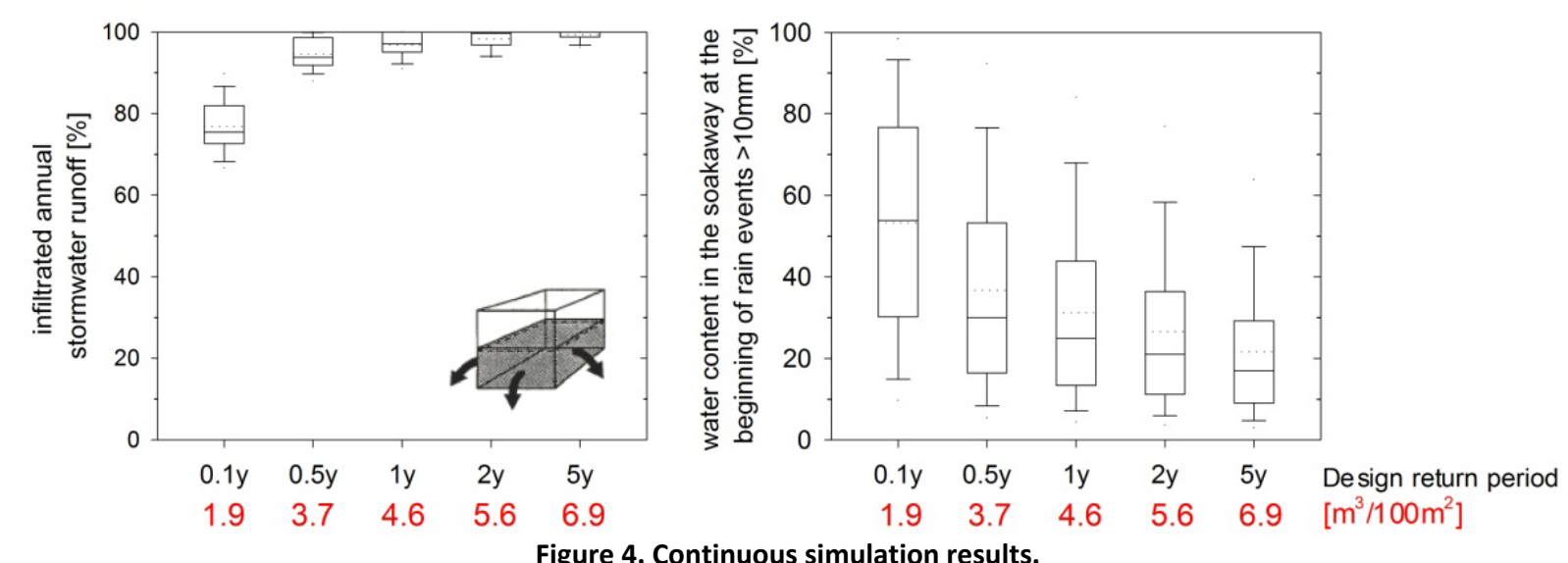

The simulated water content at the beginning of single rain events as a function of the soakaway design return period is shown in Figure 4 (right). Results show that the degree of filling is 5-94\%. Moreover, the higher the soakaway design return period, the lower the water content at the beginning of rain events; this is because the bigger the storage volume the smaller the filling ratio for a fixed input water volume. Soakaways designed for a 0.1-year return period (the selected design) are on average 53\% filled at the beginning of rain events. The peak runoff reduction capacity of soakaways is highly dependent on the available water storage at the beginning of the storm event, and it was shown that soakaways can be almost full at the beginning of an event. The detention storage coupled to the soakaway would most likely be empty at the beginning of rain events since it drains within an hour, making detention units a more robust solution for peak runoff reduction in this catchment.

Figure 3 (left) shows the annual runoff infiltrated by soakaways. The volume of infiltrated water increases with the design return period and a soakaway designed for 0.1-years return period (the selected design) can infiltrate $68-87 \%$ of the annual volume. In comparison, Roldin et al. (2012) showed that soakaways could potentially reduce CSO volume by $68 \%$ in a modelled catchment. Freni et al. (2009) showed that an infiltration unit of $0.4 \mathrm{~m}^{3} / 100 \mathrm{~m}^{2}$ in different soils could reduce $28-80 \%$ of the 6 -year stormwater runoff.

\section{Retention-detention volume combinations}

196 Figure 5 shows how the retention-detention volume combinations affect annual-runoff and single event peak-runoff reduction. Results show that a maximum of $80 \%$ peak reduction can be achieved; the volume combination ' 10 ' (Figure 5) is a better solution than '7', ' 8 ' and ' 9 ' since it scores higher in annual runoff reduction while having the same peak runoff 
main conclusions can be drawn: (1) Allocating part of a soakaway volume to detention can significantly improve peak reduction with little impact on annual runoff reductions. A soakaway designed for a 5 year return period required $69 \mathrm{~mm}$ of storage capacity (Table 1) whereas a detention volume designed for a 10 year return period required $19 \mathrm{~mm}$ of storage capacity ('The retention-detention unit design' section), showing that detention requires significantly less storage compared to retention. (2) Allocating part of a detention volume to retention can improve annual runoff reduction with little impact on peak reduction.

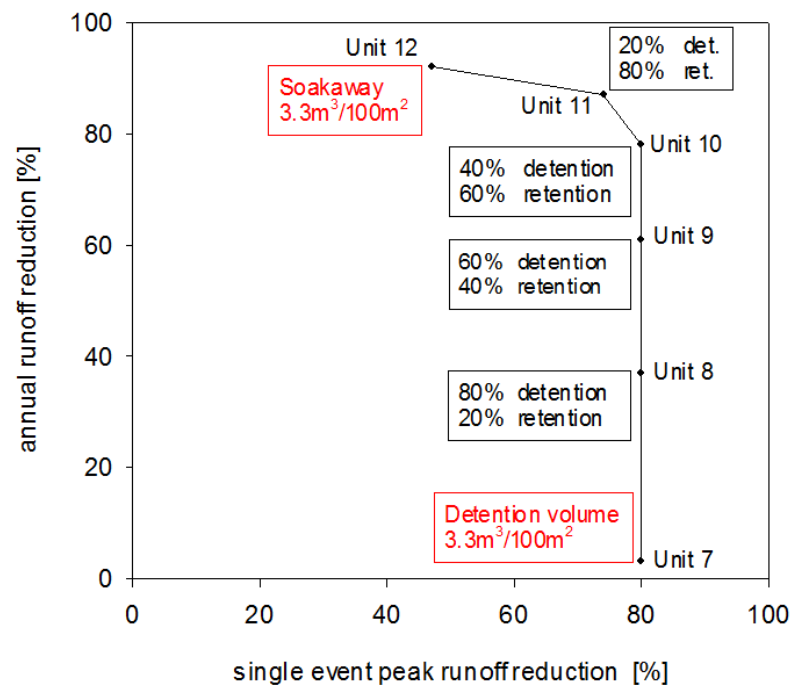

\section{CONCLUSIONS}

212 A retention-detention system was modelled. It was shown that soakaways require extremely

213 large volumes if design events are to be handled without flooding, and that the peak reduction 214 depends on the highly uncertain initial conditions. The initial conditions were determined by 215 the degree of filling of the retention volume and were found to be 5-94\% depending on the soakaway design. Coupling a detention unit to a soakaway was shown to significantly increase peak reduction. Retention-detention units were shown to be a more robust solution for peak runoff reduction because the detention volume is empty at the beginning of single events and has the capability of detaining peak flows.

A soakaway designed for a 0.1 -year return period was shown to be $53 \%$ filled on average at the beginning of rain events making it insufficient to accommodate peak flow from a design event with a 10 -year return period. Soakaways were shown to infiltrate more than $68 \%$ of the annual stormwater runoff if designed for a 0.1-year return period; which is a significant reduction in annual stormwater runoff volume to the sewer system. The $3.3 \mathrm{~m}^{3} / 100 \mathrm{~m}^{2}$ retention-detention unit was shown to avoid sewer surcharge for a design event with a 10 year return period, reducing annual runoff by $68-87 \%$ and single events peak runoff by $80 \%$.

228 This study showed that retention-detention units can reduce peak and annual runoff volumes and sewer surcharges and that adding a small detention unit to a retention unit can significantly improve peak stormwater runoff reduction. The results are specific to the Danish case study; however the modeling methodology can be applied to a broad range of conditions. The results illustrate the utility of retention-detention units, and the design presented can easily be modified to fit other climate and soil conditions. 
Andersen H. S., Tamašauskas H. and Mark O. 2004 The Full Urban Water Cycle - Modeling with MIKE URBAN. $7^{\text {th }}$ Urban Drainage Modelling, Dresden, Germany.

Antia D. D. J. 2008 Prediction of Overland Flow and Seepage Zones Associated with the Interaction of Multiple Infiltration Devices. Hydrological Processes, 22, 2595-2614.

Elliott A. H. and Trowsdale S. A. 2007 A Review of Models for Low Impact Urban Stormwater Drainage. Environmental Modelling \& Software, 22(3), 394-405.

Elliott A. H., Trowsdale S. A. and Wadhwa S. 2009 Effect of Aggregation of On-Site Storm-Water Control Devices in an Urban Catchment Model. Journal of Hydrologic Engineering, 14(9), 975-983.

Freni G., Mannina G. and Viviani G. 2009. Stormwater Infiltration Trenches: A Conceptual Modelling Approach. Water Science and Technology, 60(1), 185-99.

Keifer C. J. and Chu H. H. 1957 Synthetic storm pattern for drainage design. Journal of Hydraulic DivisionASCE, 83(HY4), 1-25.

Madsen H., Arnbjerg-Nielsen K. and Mikkelsen P. S. 2009 Update of regional intensity-duration-frequency curves in Denmark: Tendency towards increased storm intensities. Atmospheric Research, 92(3), 343-349.

Maimone M., O’Rourke D. E., Knighton J. O. and Thomas C. P. 2011 Potential Impacts of Extensive Stormwater Infiltration in Philadelphia. Environmental Engineer, 14, $29-39$.

Peters C., Keller S., Sieker H. and Jekel M. 2007 Potentials of real time control, stormwater infiltration and urine separation to minimize river impacts: dynamic long term simulation of sewer network, pumping stations, pressure pipes and waste water treatment plant. Water Science and Technology, 56(10), 1-10.

Petersen C. R., Jacobsen P., Mikkelsen P. S. 1995 Nedsivning af regnvand-dimensionering. (Stormwater infiltration-design methods). Spildevandskomiteen, Skrift, 25.

Roldin M., Fryd O., Jeppesen J., Mark O., Binning P. J., Mikkelsen P. S. and Jensen M. B. 2012 Modelling the Impact of Soakaway Retrofits on Combined Sewage Overflows in a $3 \mathrm{Km}(2)$ Urban Catchment in Copenhagen, Denmark. Journal of Hydrology, 452, 64-75.

Roldin M., Locatelli L., Mark O., Mikkelsen P. S. and Binning P. J. 2013 A Simplified Model of Soakaway Infiltration Interaction with a Shallow Groundwater Table. Journal of Hydrology, 497(0), 165-175.

Roldin M., Mark O., Kuczera G., Mikkelsen P. S. and Binning P. J. 2012 Representing Soakaways in a Physically Distributed Urban Drainage Model - Upscaling Individual Allotments to an Aggregated Scale. Journal of Hydrology, 414-415, 530-538.

Warnaars E., Larsen A. V., Jacobsen P. and Mikkelsen P. S. 1999 Hydrologic behaviour of stormwater infiltration trenches in a central urban area during 23/4 years of operation. Water Science and Technology, 39(2), 217-224.

Wong T. H. F. and Brown R. R. 2009 The Water Sensitive City: Principles for Practice. Water Science and Technology, 60(3), 673-682. 